\title{
ESTIMATING NORMAL DURATION OF RENOVATION FOR MULTISTORY APARTMENT BUILDING CONSIDERING EXTENSION-TYPE RENOVATION PROJECTS
}

\author{
Jongsik YOON (i) 1 , Ilhan $\mathrm{YU}^{2 *}$ \\ ${ }^{1}$ Department of Architectural Engineering, Ajou University, Suwon, South Korea \\ ${ }^{2}$ Future Strategy Division, Korea Research Institute for Construction Policy, Seoul, South Korea
}

Received 19 September 2018; accepted 20 November 2018

\begin{abstract}
Normal (typical) project duration is estimated at the initial stage of a renovation project and is an important reference for project control. However, its estimation has not been researched extensively owing to the complexity and uncertainties of renovation. Thus, a model was developed for predicting the duration of sustainable apartment renovation. Experts were asked to estimate a baseline schedule for extension-type renovation projects, factors that influence critical path activities, and the range of project durations considering these factors. An equation for estimating the duration of a renovation project was developed, and the range of project durations was derived using a MCS to reflect uncertainty. The proposed model was validated by applying it to actual cases. The case study shows that the model would be more suitable for complex renovation construction (i.e., more than two buildings or vertical extension). The model can be applied to various renovation projects and used as a reference for determining contract time. It can fill the knowledge gap of construction duration forecasting by adapting the concept of control activities to simplify the assessment of uncertainties in renovation of apartments, and can be applied for forecasting sustainable renovation time for other project types or in other locations.
\end{abstract}

Keywords: sustainable apartment renovation, building renovation, normal project duration, duration estimation, simulation model, MCS (Monte Carlo simulation).

\section{Introduction}

Aging infrastructure, including buildings, is a worldwide problem that needs to be addressed. As a result, the interest and investment in renovation is also increasing in the context of building sustainability (Ma, Cooper, Daly, \& Ledo, 2012). Renovation is considered a sustainable plan for aged buildings in order to save energy, increase structural safety, and improving the residential environment (Baek \& Park, 2012). Consequently, several studies have focused on effectively managing old facilities and buildings (Hsu \& Cui, 2010). Further, problems pertaining to the renovation of residential and commercial buildings are becoming more critical. In particular, in Korea, the number of old apartment buildings has increased steadily, reaching 10,030 thousand households in 2016, which is an increase of approximately 12.2 times in 30 years. It is predicted that the number of such apartments will continue to steadily increase (Figure 1). In response, renovation is being regarded as an effective alternative to increase the sustainability of aging apartment buildings (Cha,
K. H. Kim, \& C. K. Kim, 2011). However, renovation project often encounters roadblocks owing to the complexity of the process. The renovation processes are uncertain in terms of decision-making, planning, and execution compared to the process of new construction (Thuvander, Femenías, Mjörnell, \& Meiling, 2012).

Sustainable renovation is a holistic approach in which environmental, social, and economic aspects are encompassed in a balanced manner (A. N. Nielsen, Jensen, Larsen, \& S. B. Nissen, 2016). Sustainable renovation places value on social value, interior or exterior upgrade and financial aspects (Reyers \& Mansfield, 2001); thus, stakeholder consensus must be obtained. For stakeholder consensus, renovation has been studied in terms of decision support models, economics, and performance improvement (Juan, Gao, \& Wang, 2010; Kragh \& Rose, 2011; Nielsen et al., 2016; Reyers \& Mansfield, 2001). Among the factors affecting the stakeholders' consensus, the major ones are the forecasted renovation project budget and time extensions

*Corresponding author. E-mail: ihyu71@ricon.re.kr 


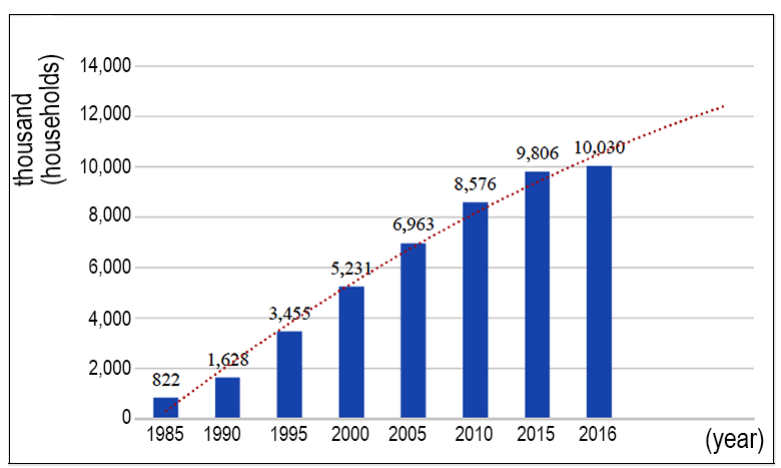

Figure 1. Number of apartments in Korea (Statistics Korea, 2017)

(Reyers \& Mansfield, 2001). Because renovation projects can increase the value of existing buildings (J. Kim, Cho, T. Kim, \& Yoon, 2018), stakeholders of renovation projects are also interested in forecasting the profitability and duration. Therefore, Cho, and Yoon (2016) performed an economic analysis for deriving the optimal time of renovation in terms of life cycle cost. Further, legislative changes and financial incentives were introduced for property owners and tenants to resolve their own interests in the renovation (Ástmarsson, Jensen, \& Maslesa, 2013). However, little attention has been focused on the duration of renovation. The project duration is crucial because it determines the temporary residence period (Suschek-Berger \& Ornetzeder, 2010). The estimated project duration also affects the project cost calculation and bid price evaluation (Irfan, Khurshid, Anastasopoulos, Labi, \& Moavenzadeh, 2011; Jin, Han, Hyun, \& Cha, 2016). However, estimating the project duration has been limited to the new construction of apartment buildings, and related research on renovation construction remains in its preliminary levels (Yoon, Jung, $\& \mathrm{Yu}, 2017)$. Because renovation is a complex process and is highly uncertain (Thuvander et al., 2012); the normal project duration of renovation cannot be generalized.

In general, when renovating buildings, first, the renovation stakeholders estimate the renovation project duration; next, the members review various alternatives for their temporary residence period according to the estimated project duration. Sometimes, however, the normal project duration estimated in the initial stages is significantly different from the actual project duration (Yoon et al., 2017). This can be regarded as a problem corresponding to project time management. One of the factors that greatly impacts the renovation process is the proficiency and skill of the project management (Olsson, Malmqvist, \& Glaumann, 2015). Sometimes contractors use novel construction management knowledge in a renovation project, negating important early-stage behavior. For example, small organizations often do not have expertise concerning management of sustainable renovation (Olsson et al., 2015). This can lead to various problems such as those corresponding to change orders and often involve high time and money costs. Therefore, a renovation period prediction model for sustainable renovation must be developed.
In this study, a project duration estimation model was developed by analyzing and supplementing the estimated baseline for the normal duration of an extension-type renovation project in the initial stage. Key variables of each activity that affects project duration were derived and quantified to estimate the normal project duration for an apartment renovation project. The results of this study can be used as a reference for determining the contract time. The normal project duration estimated herein refers to the period of the critical path (CP) for extension-type renovation: from resident migration to the apartment building's demolition, and onward to construction completion. The normal project duration (draft) of extension-type renovation construction was estimated by analyzing the design and construction characteristics and the order of unit tasks to prepare a normal project duration process chart. The simulation model was completed by quantifying factors that affect the project duration. It was then compared with existing renovation projects to verify its validity. The approach proposed in this study can be applied to forecast the sustainable renovation project time for other project types or in other locations.

\section{Literature review}

\subsection{General characteristics of renovation construction}

Depending on the degree of deterioration, the purpose of apartment building renovation construction can be categorized as repair, performance improvement, or extension. Repair and performance improvement affect the performance by changing the interior and improving facilities without changing the residential areas (K. J. Kim, Yoon, \& I. K. Kim, 2016). Extension-type renovation, however, changes the residential areas and the number of households residing in the building through vertical and horizontal extensions. In this study, extension-type renovation was examined, with a focus on vertical and horizontal extensions (Figure 2).

Apartment buildings, which are focused of this research, have been built since the 1980s. In Korea, the construction of apartments began with a rahmen structure using pillars and beams. However, due to the simple and inexpensive construction cost, the wall column structure has been used since and became the general structural form of apartment buildings in the early 1980s. However, the wall column structure system has been changed to the rahmen structure again because the wall column structure was effective in terms of workability and economy, but the variability was disadvantageous. So, the target of this research is the wall column structure system with reinforced concrete constructed in the 1980 2000s (Bang \& Park, 2017; Jang, Kim, \& Chae, 2016).

Although the type of renovation can be influenced by several factors such as the degree of deterioration, profitability, and the number of households, in this study, the type of renovation was classified only according to the degree of deterioration. The reason for this is that, strictly speaking, 
Before renovation

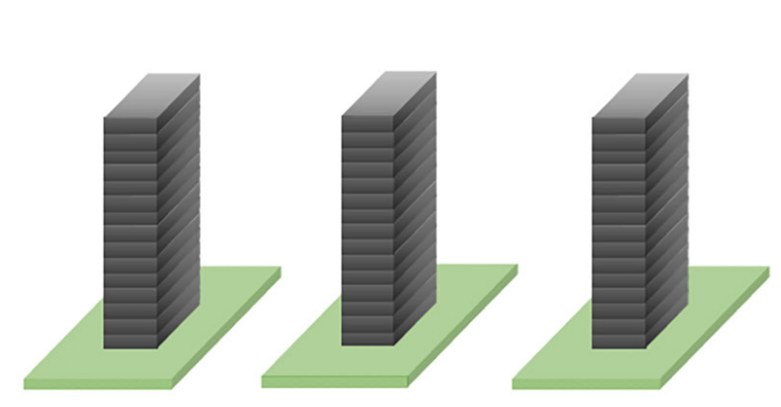

After renovation with vertical and horizontal extension

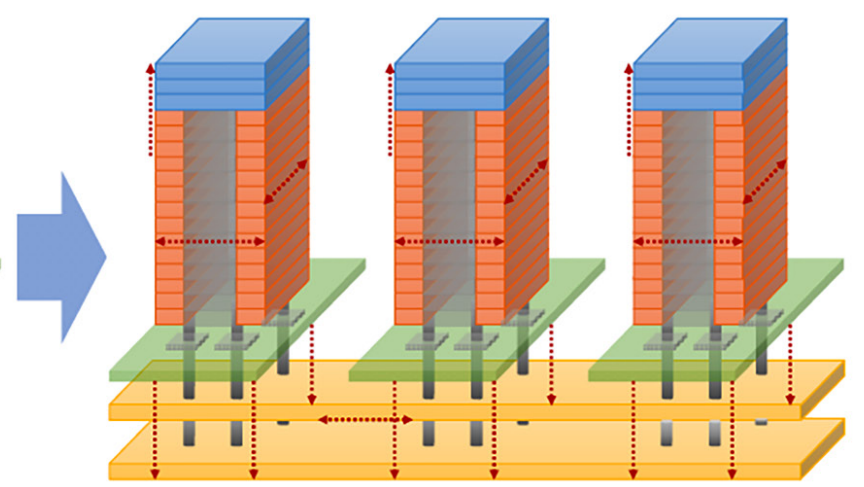

Figure 2. Concept of extension-type renovation (Yoon, Yu, \& Jung, 2018)

legally and theoretically, apartments that are more than 15 years old can have at least one horizontal and vertical extension. However, apartments that are more than 30 years old are excluded because they can be reconstructed in Korea. In other words, the renovation of apartments aged between $0-15$ years can be classified as repair type, and that of apartments aged between 15-30 years can be classified as performance improvement or extension type. By this criterion, $48.6 \%$ of the apartments can undergo extension type renovation, based on the total number of households (Table 1).

In extension-type renovation, various plans can be developed because the renovation involves the demolition of inner walls. When apartment buildings are extended, one or two floors can be extended by using lightweight walls without structural reinforcement. However, adding more floors requires the reinforcement of the foundation, pillars, and beams (Choi, 2013). Therefore, the duration of an extension-type renovation project is dependent on changes to the building structure, including demolition and foundation reinforcement. In other words, unlike new construction, renovation construction must preserve the existing structure while demolition and repair/reinforcement are performed. Thus, different construction methods and activities need to be considered (Jeong, 2015).

\subsection{Existing method of estimating project duration}

The project duration is affected by the construction cost, weather, space limitations, and productivity (Ahuja \&
Nandakumar, 1985; Edwards, 1995; Ökmen \& Öztaş, 2008). Further, project activities involve considerable uncertainty that may lead to numerous schedule variations (Herroelen \& Leus, 2005). For apartment buildings however, the workflow and input resources are generally similar. Thus, models for estimating the normal project duration based on optimization have been developed and applied to construction management (Yoon \& Yu, 2017). Because apartment building renovation for different projects is assumed to have a similar workflow for each project and almost identical productivity, the normal project duration can be estimated. Various studies have focused on predicting and managing the construction period. Construction duration estimation methods can be roughly divided as having four approaches: a standard approach based on performance data, and those using statistics, programming algorithms, and risk factors.

In South Korea and Japan, the public sector has estimated normal project durations that are applied to the construction management of apartment buildings and schools. In particular, for Korean apartment buildings, construction companies and public institutions have developed normal project period estimation models for new apartment building construction.

The normal project duration estimation model comprises construction preparation, civil work, building construction, civil work after building construction, and landscape construction periods. It is based on a 5-day work week (Land \& Housing Institute, 2015). Items to be added

Table 1. Distribution by renovation type (Statistics Korea, 2017)

\begin{tabular}{|c|c|c|c|c|c|c|c|}
\hline $\begin{array}{c}\text { Degree of } \\
\text { deterioration }\end{array}$ & $\sim 5$ years & $5-10$ years & $10-15$ years & $15-20$ years & 20-30 years & 30 years+ & Sum \\
\hline Renovation type & \multicolumn{3}{|c|}{ Repair } & \multicolumn{2}{|c|}{$\begin{array}{c}\text { Performance improvement } \\
\text { or extension }\end{array}$} & Reconstruction & - \\
\hline Household (thousand) & 1,296 & 1,491 & 1,780 & 1,836 & 3,035 & 591 & 10,030 \\
\hline Ratio (\%) & 12.9 & 14.9 & 17.7 & 18.3 & 30.3 & 5.9 & 100.0 \\
\hline $\begin{array}{l}\text { Percentage by } \\
\text { renovation type (\%) }\end{array}$ & \multicolumn{3}{|c|}{45.5} & \multicolumn{2}{|c|}{48.6} & 5.9 & 100.0 \\
\hline
\end{tabular}


include the construction scale, foundation ground conditions, and correction values according to the region. Similarly, Japan has a normal project duration estimation equation that uses the economic construction speed according to the workforce required per unit area (B. Lee, Kim, \& M. Lee, 2015).

Correction values are specified according to the scale, and construction rates of companies are categorized as grades $\mathrm{A}-\mathrm{E}$ to estimate the project duration. This is consistent with the purpose of this study and can be referred to in the context of estimating the normal project duration. However, both the Korean and Japanese project duration estimation methods target new construction rather than renovation.

Another approach for construction duration estimation is regression analysis using statistical models. In several cases, estimation equations have been derived through correlation and regression analyses. Czarnigowska and Sobotka (2014) developed a regression model based on influence factors affecting the construction duration and applied it to road construction. Lee et al. (2015) presented a regression model for the normal project duration based on the performance data of a water facility construction. Kim et al. (2016) derived a regression model for the duration of concrete-faced rock-fill dam construction in Korea based on performance data. Martin, Burrows, and Pegg (2006) verified that linear regression analysis can be used to estimate the construction duration for British factories, offices, hospitals, and schools in the project planning stage. Thus, various studies have developed regression models for construction project durations and obtained reliable results in terms of the error rate. Methods using regression models are reasonable in that they derive influence factors to estimate the project duration. These methods can be regarded as a useful tool for estimating the construction duration; however, they are not suitable for the renovation projects because these methods are deterministic, whereas renovation requires a stochastic approach.

Several studies have used the case-based reasoning (CBR) model for construction projects. Kim, An, and Kang (2004) developed and compared regression, neural network, and CBR models, which they applied to cost estimation. C. Koo, Hong, Hyun, and K. Koo (2010) developed a hybrid model using CBR for estimating both time and cost. Li, K. Lu, and Y. Lu (2017) developed and verified a project duration prediction model for high-rise construction projects using CBR. Thus, various studies have used and verified CBR for managing the time and costs of construction projects for apartment buildings, other buildings, and high-rise structures. However, CBR algorithms require a large number of samples for a high prediction accuracy and are therefore not suitable for extension-type renovation projects with limited samples. For extensiontype renovation, the number of performance data available corresponds to approximately 10 cases.

The duration of a construction project can change dynamically depending on the site conditions. Several stud- ies have focused on the uncertainty (i.e. risk) to develop project duration prediction models. Examples include the probabilistic network evaluation technique, reliability range measurement, and Monte Carlo simulation (MCS) (Ökmen \& Öztaş, 2008). While these methods can estimate the project duration ranges by reflecting risks, they fail to estimate the construction duration according to network relations between actual activities (Wang \& Demsetz, 2000). This problem can be addressed if each activity is simulated. In other words, this problem may be overcome by deriving influence factors affecting the construction duration of each project activity and simulating each influence factor. Recently, studies have started combining project scheduling and data mining techniques. Kim, Maghiar, Li, Bai, and Scott (2014) used a knowledge-based information system to identify the relationship between cost and project schedules. They developed a mathematical model based on factors such as costs, labor productivity, and material supply to calculate the schedule. Simulations have also been used to develop schedule estimation models (Hong, Cho, Hyun, \& Han, 2011).

\section{Research methodology}

This research attempts to predict the construction duration of sustainable apartment renovation under uncertainty. This study applied the concept of control activities approach used by McCrary, Leslie, Roberts, and Corley (2007) and Nguyen, Phan, and Tang (2013). The approach of controlling activities has been demonstrated to be applicable to multi-story buildings (Nguyen et al., 2013).

In the present study, surveys, case studies, and a Monte Carlo simulation (MCS) were used to develop a project duration prediction model. When existing data are insufficient, the normal project duration must be estimated by interviewing a group of experts. If influence factors can be derived from expert survey and the estimation ranges of these factors can be obtained, the normal project duration can be reasonably predicted through simulation techniques. Data was gathered from 10 renovation experts in three rounds; the renovation work breakdown structure, sequence and activities, relationships, and normal duration were obtained. Subsequently, the duration of the critical path, which was identified in previous surveys was analyzed. The factors affecting the project duration were derived and their impacts were calculated. Through this, the data from the survey were analyzed to derive equations for estimating the duration of the project based on the CP. The MCS with the Crystal Ball software is used to measure the uncertainty of the duration of the renovation project. Based on the equation of the renovation construction duration model, the scope of the total project duration was estimated (Figure 3). This estimation process for a normal project duration is expected to reflect the special characteristics of extension-type renovation, identify influence factors that affect the project duration, and reliably estimate the normal project duration in the initial stages. 


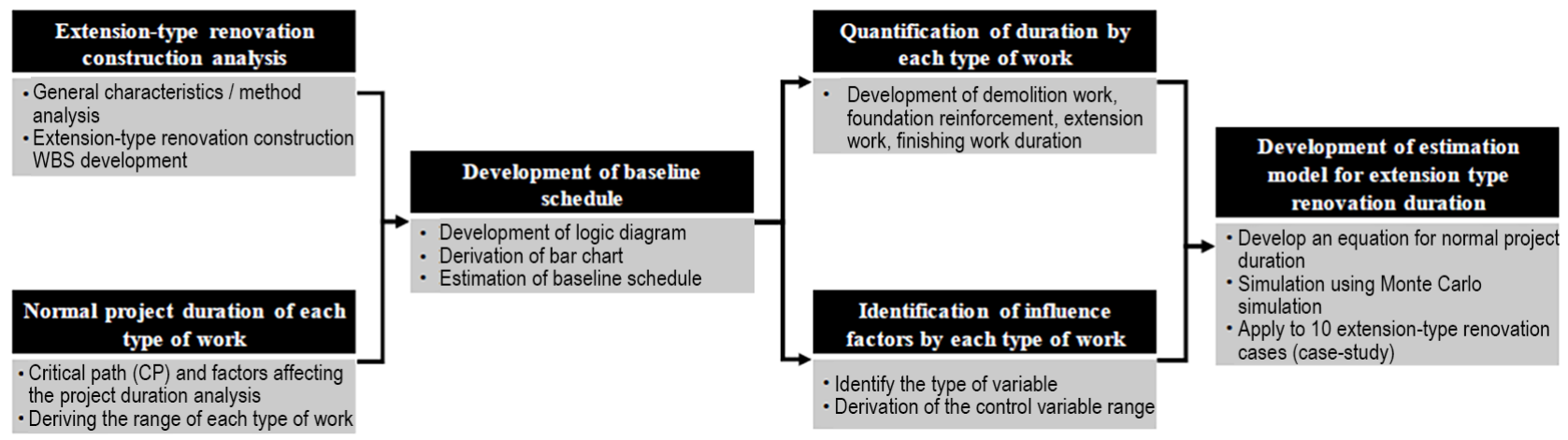

Figure 3. Research method

\section{Estimation of normal project duration for extension-type renovation}

Although the potential market for renovation is large, with 3 million households or more, the number of extensiontype renovation projects for apartment building is limited to date at less than 10 cases, and less than five construction companies have performed extension-type renovation. Owing to such few cases available for analysis, a Delphi analysis based on expert interviews was used to estimate the normal project duration of extension-type renovation. Although limited to a few cases and a few experts, this case study is representative with the experts being experienced professionals. Therefore, the results of the Delphi survey are more reliable than those that could be obtained by mixing the opinions of similar experts. In the Delphi analysis, the number of experts involved is important. Although none of the studies found a significant correlation between the number of panelists and efficiency, the involvement of at least eight specialists is considered to be reasonable (Brockhoff, 1975; Hallowell \& Gambatese, 2010). Ten top experts, who are representative of the companies in Korea, were selected to participate in the survey carried out in this work. Table 2 describes the analysis process based on interviews with experts, including site supervisors of construction companies that performed extension-type renovation. Ten experts were consulted for the Delphi analysis; the panel involved construction or schedule management experts who directly participated in extension-type renovation.

\subsection{CP Estimation of renovation construction}

The first priority when estimating the normal project duration is to estimate the $\mathrm{CP}$ of the entire construction project. Unlike new construction, renovation must maintain the existing structure, and so there are separate considerations for the application method of each work type. Table 3 summarizes the renovation activities, basic methods of construction, and characteristics.

The proposed activity classification was based on existing renovation construction cases and verified by expert interviews (A1 in Table 2). The CP for project duration estimation was determined through in-depth expert interviews, and a survey was conducted to determine important milestones. Table 4 presents the derived $\mathrm{CP}$ and milestones.

The CP consists of eight activities: migration, temporary works, demolition, foundation reinforcement, structural extension works, finishing works, external works, and completion cleaning. Repair/reinforcement, earthwork and sheathing work, mechanical facility construction, and electric facility construction are classified as concurrent activities. Some activities within the $\mathrm{CP}$ are concurrently performed; for example, the finishing work starts when construction of the sixth-floor frame is completed. Therefore, milestones are important for the baseline schedule, and the estimated project duration baseline may change according to the milestones. Table 5 presents major milestones according to the activity flow.

The normal construction duration for each activity was derived based on the above $\mathrm{CP}$ and major milestones, as presented in Table 6. For activities 4, 5, 6, 8 and 11, the construction duration that was applied to the $\mathrm{CP}$ differed from the total construction duration. This was because of concurrent construction.

In addition, the baseline for the normal project duration was estimated for 15 aboveground floors and two underground floors. This is because South Korea's current regulations allow buildings of 15 floors or more to be extended by up to three floors.

Table 2. Overview of the Delphi analysis

\begin{tabular}{|c|c|l|}
\hline Code & Round & \multicolumn{1}{|c|}{ Interview contents } \\
\hline A1 & 1 & Critical path (CP) and milestones of extension renovation construction \\
A2 & 2 & Influence factors affecting the construction period \\
A3 & 3 & Range of construction durations according to influence factors \\
\hline
\end{tabular}


Table 3. Activity code and description

\begin{tabular}{|c|c|c|c|}
\hline $\begin{array}{l}\text { Activity } \\
\text { code }\end{array}$ & Activity description & Method of construction & Characteristics \\
\hline 1 & Migration & - & Migration to a temporary residence \\
\hline 2 & Temporary works & Scaffolding, gondola, system scaffolding etc. & $\begin{array}{l}\text { Consider material loading, securing of } \\
\text { workplace, complaints etc. }\end{array}$ \\
\hline 3 & Demolition & Breaker, boring machine, dynamite etc. & $\begin{array}{l}\text { Demolition by workforce or small-size } \\
\text { equipment }\end{array}$ \\
\hline 4 & $\begin{array}{l}\text { Structural repair/ } \\
\text { reinforcement }\end{array}$ & $\begin{array}{l}\text { Steel plate reinforcement, prestress, extension } \\
\text { of section, fibre reinforcement, H-beam } \\
\text { reinforcement, steel brace reinforcement etc. }\end{array}$ & $\begin{array}{l}\text { Review of treatment methods of joints } \\
\text { Review of type of crack (warp, shear, } \\
\text { expansion) }\end{array}$ \\
\hline 5 & $\begin{array}{l}\text { Earthworks and } \\
\text { sheathing works }\end{array}$ & $\begin{array}{l}\text { Soldier pile wall, soil cement wall (S.C.W), cast } \\
\text { in place pile (C.I.P) diaphragm wall } \\
\end{array}$ & $\begin{array}{l}\text { Consideration of site conditions such as the } \\
\text { surrounding environment }\end{array}$ \\
\hline 6 & $\begin{array}{l}\text { Foundation } \\
\text { reinforcement }\end{array}$ & Micro-file, underpinning method etc. & $\begin{array}{l}\text { Consideration of site conditions such as } \\
\text { interference with existing foundation }\end{array}$ \\
\hline 7 & $\begin{array}{l}\text { Structural extension } \\
\text { works }\end{array}$ & $\begin{array}{l}\text { Joint installation, anchor bolts, RC slab or deck } \\
\text { slab }\end{array}$ & $\begin{array}{l}\text { Decision whether to use RC or steel when } \\
\text { carrying out extension work }\end{array}$ \\
\hline 8 & Finishing works & \multirow{5}{*}{\multicolumn{2}{|c|}{ Similar to those of new construction }} \\
\hline 9 & Mechanical works & & \\
\hline 10 & Electrical works & & \\
\hline 11 & External works & & \\
\hline 12 & Completion cleaning & & \\
\hline
\end{tabular}

Table 4. Critical path of renovation construction

\begin{tabular}{|c|c|c|}
\hline Division & Critical path sequence & Interview contents \\
\hline 1 & $1-2-3 \cdot 4 \cdot 5-6-7 \cdot 8-12$ & $\begin{array}{l}(\cdot) \text { indicates concurrent } \\
\text { tasks }\end{array}$ \\
\hline
\end{tabular}

Table 5. Milestones according to activity flow

\begin{tabular}{|c|l|l|}
\hline $\begin{array}{c}\text { Activity } \\
\text { flow }\end{array}$ & \multicolumn{1}{|c|}{ Major milestones } & \multicolumn{1}{c|}{ Remark } \\
\hline $1-2$ & Scaffolding installation & $\begin{array}{l}\text { Establishment of a } \\
\text { scaffolding system for } \\
\text { the preservation of } \\
\text { existing building }\end{array}$ \\
\hline $2-3 \cdot 4 \cdot 5$ & $\begin{array}{l}\text { Tower crane (T/C) } \\
\text { installation } \\
\text { Structural repair/ } \\
\text { reinforcement } \\
\text { completion date }\end{array}$ & $\begin{array}{l}\text { T/C installation for } \\
\text { demolished waste } \\
\text { and major materials } \\
\text { transportation }\end{array}$ \\
\hline $3 \cdot 4 \cdot 5-6$ & $\begin{array}{l}\text { Foundation } \\
\text { reinforcement work } \\
\text { starting date }\end{array}$ & $\begin{array}{l}\text { The foundation has a } \\
\text { large impact on the } \\
\text { whole construction, so } \\
\text { it is selected as a major } \\
\text { milestone }\end{array}$ \\
\hline $6-7 \cdot 8$ & $\begin{array}{l}\text { Hoist installation } \\
\text { Completion date of } \\
\text { structural extension } \\
\text { works/scaffolding removal } \\
\text { Finishing work } \\
\text { completion date }\end{array}$ & $\begin{array}{l}\text { Finishing work in } \\
\text { conjunction with hoist } \\
\text { installation work }\end{array}$ \\
\hline $7 \cdot 8-12$ & $\begin{array}{l}\text { Construction completion } \\
\text { date }\end{array}$ & - \\
\hline
\end{tabular}

The construction duration was estimated to be 30 months in total, and the approximate total construction period was derived by determining the construction duration per floor. The construction can be schematized using a logic diagram for Table 6 and the bar chart in Figure 4.

\subsection{Derivation of equation for normal project duration estimation}

To predict the renovation duration, a formula is required to calculate the period for each work type. The method of calculating the normal duration is expressed as the product of the general activity duration and the factor value that influences their activity. The basic concept of estimating the construction duration for each activity is given as:

$$
d=t \times a,
$$

where $d$ is the normal project duration, $t$ is the duration per activity, and $a$ is the duration of variables that affect each activity's duration. $t$ is expressed as the duration of one activity per floor and $a$ is expressed as the total of all floors. The key to the estimation method lies in identifying and quantifying the factors that affect each activity. If the factors that affect each activity of the CP can be identified and quantified to derive the construction duration of each activity, the total construction duration can be estimated accordingly. The results of expert interviews (A2 in Table 2) regarding baseline duration cases showed that migration, temporary works, external works, and completion cleaning (i.e., activities $1,2,11$, and 12) can be specified as fixed values. 


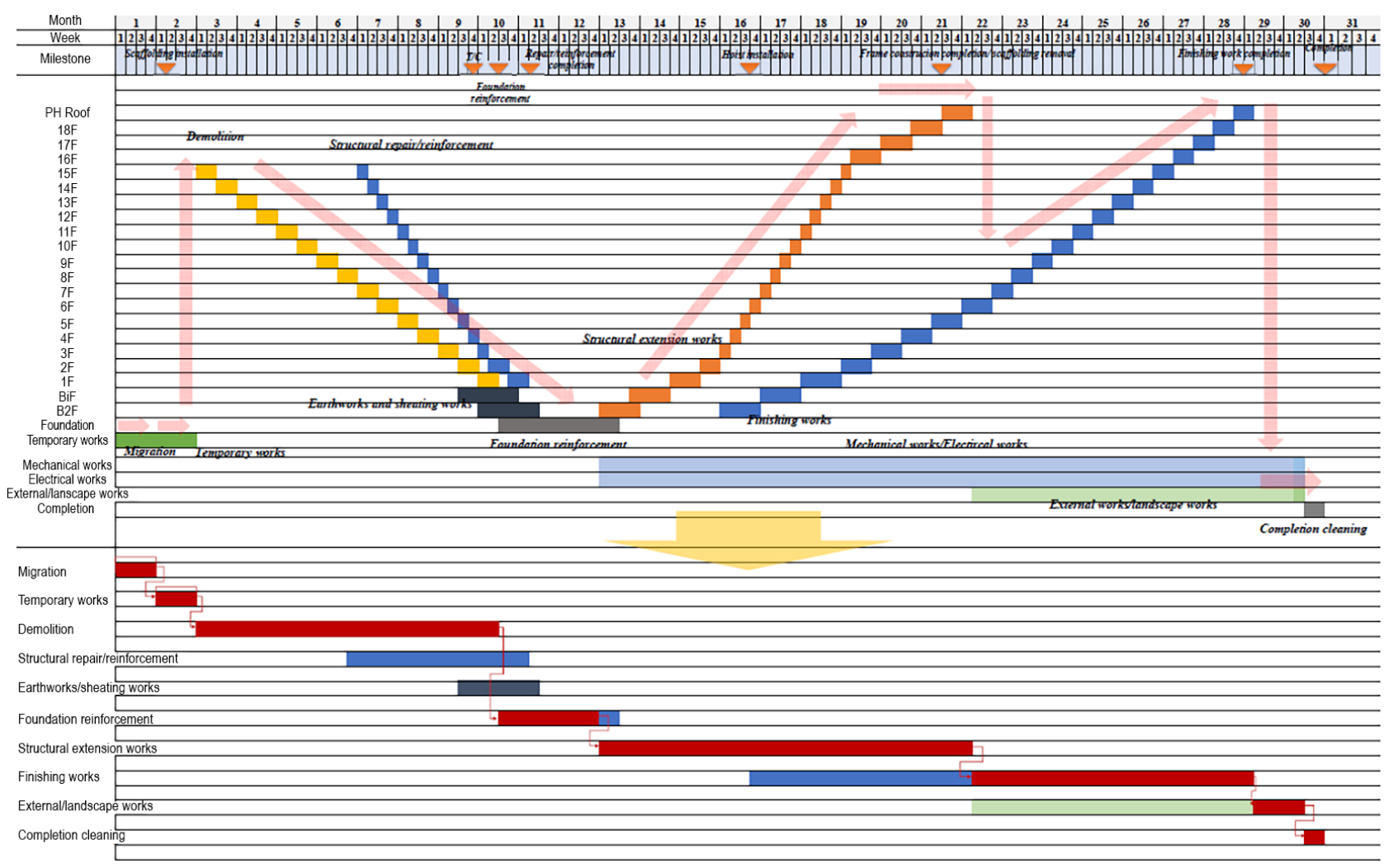

Figure 4. Baseline schedule

These activities are very similar to those of existing apartment construction, and their construction durations are mostly constant unless there are external factors. Because the construction duration may change with each case for demolition, foundation reinforcement, structural extension works, and finishing works (i.e. activities 3 and $6-8)$, these activities were used to analyze factors that affect the construction duration.

\subsection{Factors of each activity that affect construction duration}

Table 7 presents the factors that affect the construction duration of individual activities. It consists of 13 factors from demolition work to finishing work. Factors listed in each activity are categorized and presented. In the case of a control variable, it is a probabilistic factor that is

Table 6. Normal project duration baseline for renovation

\begin{tabular}{|l|c|c|c|}
\hline \multicolumn{1}{|c|}{ Activity } & $\begin{array}{c}\text { Total construction } \\
\text { duration (months) }\end{array}$ & $\begin{array}{c}\text { Construction duration } \\
\text { applied to CP }\end{array}$ & Remarks \\
\hline (1) Migration & 1.00 & 1.00 & Fixed value \\
\hline (2) Temporary works & 1.00 & 1.00 & Fixed value \\
\hline (3) Demolition & 7.50 & 7.50 & 2 weeks per floor, 15 aboveground floors \\
\hline (4) Structural repair/reinforcement & 4.25 & 0.00 & 1 week per floor, 15 aboveground floors \\
\hline (5) Earthworks and sheathing works & 2.00 & 0.00 & Concurrent construction \\
\hline (6) Foundation reinforcement & 3.00 & 2.50 & 4 weeks per floor, 2 underground floors \\
\hline (7) Structural extension works & 9.25 & 9.25 & 1 week per floor, 15 aboveground floors \\
\hline (8) Finishing works & 13.25 & 7.00 & Concurrent construction \\
\hline (9) Mechanical works & 15.50 & 0.00 & - \\
\hline (10) Electrical works & 15.50 & 0.00 & - \\
\hline (11) External works & 8.25 & 1.25 & Fixed value \\
\hline (12) Completion cleaning & 0.50 & 0.50 & Fixed value \\
\hline Total & - & 30.00 & - \\
\hline
\end{tabular}


Table 7. Factors affecting the work duration of individual activities

\begin{tabular}{|l|l|c|l|}
\hline \multicolumn{1}{|c|}{ Activity } & \multicolumn{1}{|c|}{ Influence factor } & \multicolumn{1}{c|}{ Unit } & \multicolumn{1}{c|}{ Variable type } \\
\hline $\begin{array}{l}\text { Demolition } \\
\left(d_{3}\right)\end{array}$ & Duration per floor $\left(t_{3}\right)$ & month/story & Control variable \\
\cline { 2 - 4 } & Ground floor before renovation $\left(a_{3}\right)$ & story & $\begin{array}{l}\text { Variable with project-specific } \\
\text { information }\end{array}$ \\
\hline $\begin{array}{l}\text { Foundation reinforcement } \\
\left(d_{6}\right)\end{array}$ & Daily construction amount $\left(t_{6}\right)$ & $\mathrm{m} /$ day & Control variable \\
\cline { 2 - 5 } & Reinforcement ratio $\left(a_{6-1}\right)$ & $\mathrm{m} / \mathrm{m}^{2}$ & Control variable \\
\cline { 2 - 5 } & Land area $\left(a_{6-2}\right)$ & $\mathrm{m}^{2}$ & $\begin{array}{l}\text { Variable with project-specific } \\
\text { information }\end{array}$ \\
\hline $\begin{array}{l}\text { Horizontal extension works } \\
\left(d_{7-1}\right)\end{array}$ & Duration per floor $\left(t_{7-1}\right)$ & month/story & Control variable \\
\cline { 2 - 5 } & $\begin{array}{l}\text { Total remodeled floors aboveground } \\
\left(a_{7-1}\right)\end{array}$ & story & $\begin{array}{l}\text { Variable with project-specific } \\
\text { information }\end{array}$ \\
\hline $\begin{array}{l}\text { Vertical extension works } \\
\left(d_{7-2}\right)\end{array}$ & Duration per floor $\left(t_{7-2}\right)$ & month/story & Control variable \\
\cline { 2 - 5 } & Vertical extension floors + roof $\left(a_{7-2}\right)$ & story & $\begin{array}{l}\text { Variable with project-specific } \\
\text { information }\end{array}$ \\
\hline \multirow{2}{*}{$\begin{array}{l}\text { Underground framing } \\
\left(d_{7-3}\right)\end{array}$} & Duration per floor $\left(t_{7-3}\right)$ & month/story & Control variable \\
\cline { 2 - 5 } & Underground floors $\left(a_{7-3}\right)$ & story & $\begin{array}{l}\text { Variable with project-specific } \\
\text { information }\end{array}$ \\
\hline $\begin{array}{l}\text { Finishing works } \\
\left(d_{8}\right)\end{array}$ & Duration per floor $\left(t_{8}\right)$ & Control variable \\
\cline { 2 - 5 } & $\begin{array}{l}\text { Total finishing work duration-framing } \\
\text { overlapping duration }\left(a_{8}\right)\end{array}$ & $\begin{array}{l}\text { Variable with project-specific } \\
\text { information }\end{array}$ \\
\hline
\end{tabular}

determined by optimistic, expected, and pessimistic values. These factor values result in a range of construction durations. Variables with project-specific information are deterministic values that are determined for each case. This is determined by the aboveground floor, underground floor, and area of the apartment to be renovated. A detailed description for each activity follows.

The demolition duration is determined by the demolition duration per floor and number of aboveground floors. The average demolition duration required for one floor is about 2 weeks. If the labor and equipment input are increased, it can be less than 2 weeks. The normal duration for demolition according to the above influence factors can be estimated as follows:

$$
d_{3}=t_{3} \times a_{3} .
$$

The construction duration for foundation reinforcement may change according to the daily construction quantity of piles $(\mathrm{m})$, reinforcement ratio, and land area $\left(\mathrm{m}^{2}\right)$. The reinforcement ratio refers to the length $(\mathrm{m})$ of the foundation to be reinforced per unit area $\left(\mathrm{m}^{2}\right)$, and the average value from existing performance data was applied. The land area is determined for each case, but the daily construction amount and reinforcement ratio are given as ranges because they change according to the existing foundation conditions and productivity. Because these are difficult to estimate, the maximum and minimum values were assumed from expert interviews (A3 in Table 2). The foundation reinforcement duration is estimated as follows:

$$
d_{6}=\frac{a_{6-1} \times a_{6-2}}{t_{6}} \times \frac{1}{30} .
$$

For structural extension works, the duration per floor must be divided into three types because horizontal extension works, vertical extension works, and underground works require different construction methods and resources. After the construction duration per floor is assumed for each work component, the normal duration for structural extension works can be estimated as follows:

$$
d_{7}=t_{7-1} \times a_{7-1}+t_{7-2} \times a_{7-2}+t_{7-3} \times a_{7-3} .
$$

The normal duration for finishing work can be estimated based on the construction duration per floor. Among the major milestones, the hoist installation time was set to represent the completion of the sixth-floor structural extension works, and the period after the completion of the structural extension works was set as the finishing works duration:

$$
d_{8}=t_{8} \times a_{8} .
$$

Based on the above equations for estimating the duration of each activity, the normal duration for the total renovation construction project (D) can be estimated as follows:

$$
\begin{aligned}
D= & t_{1}+t_{2}+\left(t_{3} \times a_{3}\right)+\left(\frac{a_{6-1} \times a_{6-2}}{t_{6}} \times \frac{1}{30}\right)+ \\
& \left(t_{7-1} \times a_{7-1}+t_{7-2} \times a_{7-2}+t_{7-3} \times a_{7-3}\right)+ \\
& \left(t_{8} \times a_{8}\right)+t_{11}+t_{12} .
\end{aligned}
$$


Table 8. Range of construction durations for each activity

\begin{tabular}{|c|c|c|c|c|}
\hline $\begin{array}{l}\text { Influence } \\
\text { factor }\end{array}$ & Unit & $\begin{array}{l}\text { Optimistic } \\
\text { value }\end{array}$ & $\begin{array}{l}\text { Most likely } \\
\text { value }\end{array}$ & $\begin{array}{l}\text { Pessimistic } \\
\text { value }\end{array}$ \\
\hline$t_{3}$ & $\begin{array}{l}\text { month/ } \\
\text { story }\end{array}$ & 0.25 & 0.50 & 0.75 \\
\hline$t_{6}$ & m/day & 200 & 250 & 300 \\
\hline$a_{6-1}$ & $\mathrm{~m} / \mathrm{m}^{2}$ & 1.00 & 1.25 & 2.00 \\
\hline$t_{7-1}$ & $\begin{array}{l}\text { month/ } \\
\text { story }\end{array}$ & 0.25 & 0.28 & 0.32 \\
\hline$t_{7-2}$ & $\begin{array}{l}\text { month/ } \\
\text { story }\end{array}$ & 0.74 & 0.76 & 1.00 \\
\hline$t_{7-3}$ & $\begin{array}{l}\text { month/ } \\
\text { story }\end{array}$ & 0.80 & 1.00 & 1.50 \\
\hline$t_{8}$ & $\begin{array}{l}\text { month/ } \\
\text { story }\end{array}$ & 0.25 & 0.50 & 0.75 \\
\hline
\end{tabular}

Equation (6) can be used to estimate the construction duration of extension-type renovation. If case information variables are known, the total construction duration can be approximated. Because control variables are not deterministic but probabilistic, they are derived as ranges. In this study, values estimated by MCS were used as control variables because this method is useful for deriving range values from a probability distribution of uncertain values (Nguyen et al., 2013).

To use MCS, the maximum value, minimum value, and distribution of control variables must be assumed. The maximum and minimum values of activities were derived from existing expert (A3 in Table 2) interviews, as given in Table 8. However, because the distribution is hard to predict, it was assumed to be triangular based on the program evaluation review technique scheduling concept.

\section{Results and discussion}

The normal project duration estimation model proposed in this study was compared with 10 extension-type renovation construction cases performed in South Korea. Table 9 presents the basic information of each case. For each case, 10,000 MCS cycles were performed.

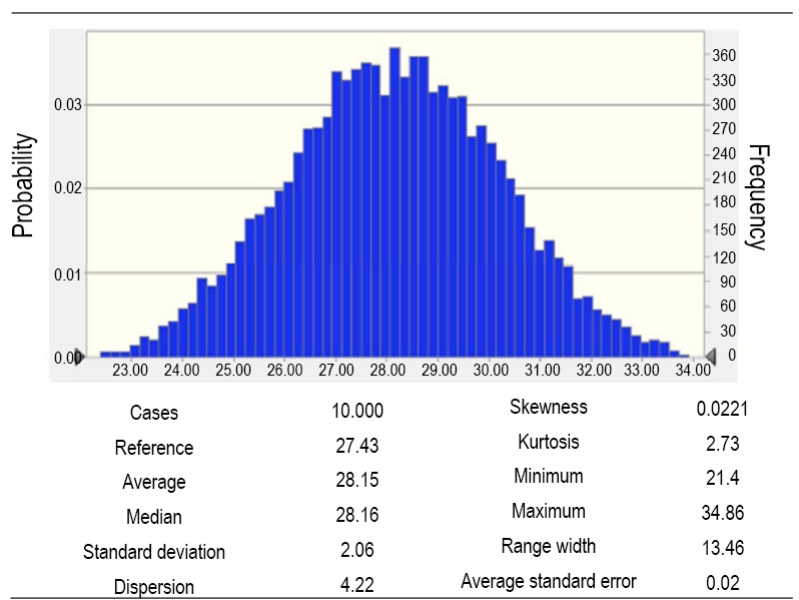

Figure 5. Simulation result for case 1

Case 1 can be assumed to be the most representative case; its results are given in Figure 5. The variables were assumed to have a triangular distribution. The reference value in the simulation was 27.43 months, which is close to the actual 27 months. The minimum and maximum values were 21.40 and 34.86 months, so it is possible to predict optimistic and pessimistic values for the construction duration. In this case, the construction began under the assumption that the normal project duration would be up to 33 months. In other words, the range values from the simulation are also somewhat reliable for predicting the construction duration in the initial stage.

The results of the other nine cases were also reviewed. Figure 6 presents the derived construction duration reference values. A comparison of the estimated and actual construction durations revealed differences of 0.43-6.66 months. These differences are within a standard deviation of 1 or 2 for the reference values, which indicates that the construction duration estimation model for extensiontype renovation is reliable. In cases where the standard deviation exceeded 1 , it was difficult to reasonably estimate the construction period. Case studies were analyzed using two buildings and vertical extension as a reference. Thus, the analysis of complex-level (i.e., more than two buildings or vertical extension) extension-type renovation construction showed significantly reduced errors of 0.43-3.94 months. In other words, the proposed construction dura-

Table 9. Case description

\begin{tabular}{|c|c|c|c|c|c|c|c|c|c|c|}
\hline Category & Case 1 & Case 2 & Case 3 & Case 4 & Case 5 & Case 6 & Case 7 & Case 8 & Case 9 & Case 10 \\
\hline Land area $\left(\mathrm{m}^{2}\right)$ & 14,779 & 7,167 & 2,182 & 6,762 & 2,858 & 3,186 & 6,532 & 3,557 & 18,329 & 11,500 \\
\hline No. of main buildings & 5 & 2 & 1 & 1 & 1 & 1 & 1 & 1 & 5 & 3 \\
\hline Floors before renovation & 15 & 10 & 12 & 14 & 12 & 12 & 15 & 18 & 12 & 12 \\
\hline Floors after renovation & 16 & 11 & 12 & 14 & 12 & 13 & 16 & 19 & 13 & 12 \\
\hline $\begin{array}{l}\text { Underground floors before } \\
\text { renovation }\end{array}$ & - & 1 & 1 & 1 & 2 & 1 & 1 & 2 & 1 & - \\
\hline $\begin{array}{l}\text { Underground floors after } \\
\text { renovation }\end{array}$ & 2 & 2 & 1 & 1 & 2 & 1 & 2 & 3 & 2 & 1 \\
\hline
\end{tabular}




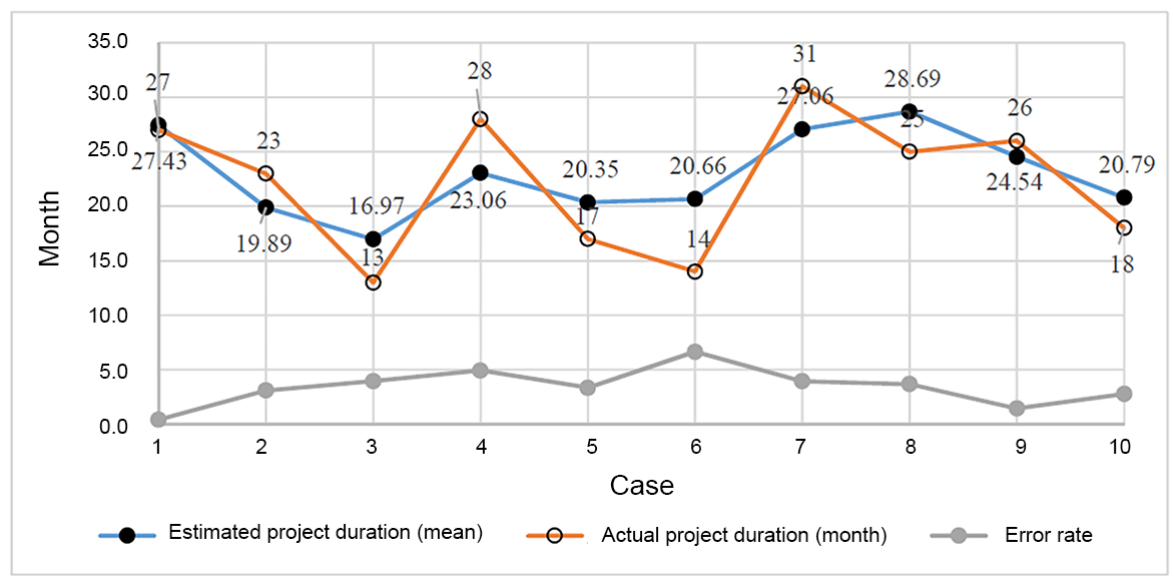

Figure 6. Simulation results

tion estimation model was found to be more suitable for complex renovation construction. The higher applicability of two or more buildings and vertical extension is due to the influence of the duration of the foundation reinforcement work. Specifically, there are two main reasons: First, the foundation reinforcement work duration is affected by the land area. A larger land area corresponds to a requirement of more foundation reinforcement. In other words, in the case of renovation works with a small number of buildings, the foundation reinforcement duration differs from the baseline schedule because the amount of foundation reinforcement is relatively low. This can be corrected by adjusting the productivity (daily construction amount, reinforcement ratio) of the reinforcement work. Second, it relates to vertical extension and underground space expansion. The renovation duration can vary greatly depending on the scale of vertical extension and the scale of underground space expansion. Since the underground space is used for parking, underground space expansion is usually added to apartment complexes that lack parking spaces. The baseline schedule was modeled assuming vertical extension and underground expansion. Therefore, cases $3,4,5$, and 6 , which were not accompanied by vertical extension and underground expansion, had relatively large error rates. Future research needs to refine the influence factors of vertical extension and underground space expansion works. These factors can be used to lower the error rates. Furthermore, cases that showed a difference of up to 6.6 months require correction and new definitions of the influence factors of other activities.

\section{Conclusions}

This study focused on developing a reliable way to estimate the total construction duration. A baseline schedule was developed based on the work breakdown structure, factors that affect $\mathrm{CP}$ activities were derived, and a construction duration estimation equation and the MCS method were used. Factors that affect the scope and duration of construction were derived from a Delphi analysis owing to an insufficient number of cases. Case studies revealed that the actual construction duration was within one or two standard deviations of the simulation results, which validates the proposed construction duration estimation model. The proposed model produced reliable results with a standard deviation of less than 1 for complex-level extension-type renovation construction with two or more buildings or vertical extension and underground space expansion. This shows that the proposed model is most suitable for complex-level extension-type renovation construction.

The proposed model is useful because it can predict the construction duration with some initial information, such as the number of aboveground floors before and after renovation, number of underground floors before and after renovation, and land area. It can be applied in the initial stage by various renovation stakeholders. Thus, the temporary residence period after migration can be approximated with the model. Furthermore, changes in construction duration within the scopes of extension, demolition, and reinforcement can be estimated and compared in the design stage. This will help the decision-making of stakeholders, including the owner, designer, and constructor. Various applications are expected, including contracts that reflect the construction duration. However, the proposed model tends to generate errors when the number of buildings is two or less and without vertical extension or underground space expansion. This suggests that novel approaches are required, such as developing correction values or changing the criteria for control variables. The addition and analysis of changes due to climate or considerations due to regional factors will lead to a more reasonable construction duration estimation model. The lack of task-level analysis for each activity remains a limitation of this study. In addition, there is no consideration of dry method, such as modular method, in this research. The modular construction method has some advantages, in that, it can increase the ease of construction and shorten the structural reinforcement work due to the weight reduction. This is a factor that can affect the renovation time (Pihelo, Kalamees, \& Kuusk, 2017). It may affect major construction work such as foundation reinforcement work $\left(d_{6}\right)$, vertical extension 
work $\left(d_{7-2}\right)$, and finishing work $\left(d_{8}\right)$. Since the wall column structure apartments are not space-variable, it is difficult to apply the infill-type modular construction method. But, in future research, it is necessary to analyze the construction duration, which is changed by the modular construction method in the case of the rahmen-type structure apartment renovation. So, it is necessary to supplement the construction duration estimation model by adding new factors of construction period change by modular construction method. Additionally, only 10 experts participated in the analysis, which may be insufficient to conduct a statistical analysis, and it is difficult to perform statistical verification because of the small number of cases. Therefore, it is necessary to increase the credibility by adding case studies to the currently ongoing projects that have reached the construction stage. Furthermore, for more global applicability, foreign experts such as those from Hong Kong, Singapore, and Japan, who have renovation project experience, must be added. Despite this, the developed model represents a great stride forward in accurately estimating the duration of extension-type renovation. This model fills the knowledge gap of the predicting duration by adapting the concept of controlling activity and simulation of certain uncertainties in sustainable renovation project. Evaluating only $\mathrm{CP}$ activities duration can usefully be applied because it can be less complex than evaluating all the activities and risks. The case application of the model is limited to the extension-type apartment renovation in Korea, but the approach proposed in this study can be attempted to forecast sustainable renovation project time for other project types or in other locations.

\section{Acknowledgements}

This work was supported by the Residential Environment Research Program funded by the Ministry of Land, Infrastructure and Transport of the Korean government under Grant [number 18RERP-B099826-04].

\section{Author contributions}

JY contributed to the conceptualization and organized the model, analyzed the data, and prepared the draft. IY conducted project administration, collected the dataset, and finalized the paper. All authors contributed to authoring this paper.

\section{Disclosure statement}

The authors declare no conflict of interest.

\section{References}

Ahuja, H. N., \& Nandakumar, V. (1985). Simulation model to forecast project completion time. Journal of Construction Engineering and Management, 111(4), 325-342.

https://doi.org/10.1061/(ASCE)0733-9364(1985)111:4(325)
Ástmarsson, B., Jensen, P. A., \& Maslesa, E. (2013). Sustainable renovation of residential buildings and the landlord/tenant dilemma. Energy Policy, 63, 355-362.

https://doi.org/10.1016/j.enpol.2013.08.046

Baek, C. H., \& Park, S. H. (2012). Changes in renovation policies in the era of sustainability. Energy and Buildings, 47, 485-496. https://doi.org/10.1016/j.enbuild.2011.12.028

Bang, J. D., \& Park, J. Y. (2017). Structural development in long life housing of LH. Review of Architecture and Building Science, 61(8), 14-17.

Brockhoff, K. (1975). The performance of forecasting groups in computer dialogue and face-to-face discussion. In H. A. Linstone \& M. Turoff (Eds.), The Delphi method: Techniques and applications (pp. 285-311). Reading, MA: Addison-Wesley.

Cha, H. S., Kim, K. H., \& Kim, C. K. (2011). Case study on selective demolition method for refurbishing deteriorated residential apartments. Journal of Construction Engineering and Management, 138(2), 294-303.

https://doi.org/10.1061/(ASCE)CO.1943-7862.0000424

Cho, K., \& Yoon, Y. (2016). Decision support model for determining cost-effective renovation time. Journal of Management in Engineering, 32(3), 04015051.

https://doi.org/10.1061/(ASCE)ME.1943-5479.0000418

Choi, S. (2013). Remodeling technology practice. Seoul: Kimoondang.

Czarnigowska, A., \& Sobotka, A. (2014). Estimating construction duration for public roads during the preplanning phase. Journal of Engineering, Project, and Product Management, 4(1), 26-35. https://doi.org/10.32738/JEPPM.201401.0004

Edwards, L. (1995). Practical risk management in the construction industry. London: Thomas Telford Ltd. https://doi.org/10.1680/prmitci.20641

Hallowell, M. R., \& Gambatese, J. A. (2010). Qualitative research: Application of the Delphi method to CEM research. Journal of Construction Engineering and Management, 136(1), 99-107. https://doi.org/10.1061/(ASCE)CO.1943-7862.0000137

Herroelen, W., \& Leus, R. (2005). Project scheduling under uncertainty: Survey and research potentials. European Journal of Operational Research, 165(2), 289-306.

https://doi.org/10.1016/j.ejor.2004.04.002

Hong, T., Cho, K., Hyun, C., \& Han, S. (2011). Simulation-based schedule estimation model for ACS-based core wall construction of high-rise building. Journal of Construction Engineering and Management, 137(6), 393-402. https://doi.org/10.1061/(ASCE)CO.1943-7862.0000300

Hsu, S.-C., \& Cui, Q. (2010). A decision model for technology selection in renovation project planning. In Construction Research Congress 2010: Innovation for Reshaping Construction Practice (pp. 1234-1243). https://doi.org/10.1061/41109(373)124

Irfan, M., Khurshid, M. B., Anastasopoulos, P., Labi, S., \& Moavenzadeh, F. (2011). Planning-stage estimation of highway project duration on the basis of anticipated project cost, project type, and contract type. International Journal of Project Management, 29(1), 78-92. https://doi.org/10.1016/j.ijproman.2010.01.001

Jang, H. J., Kim, T. H., \& Chae, C. U. (2016). CO2 emissions and cost by floor types of public apartment houses in South Korea. Sustainability, 8(5), 445. https://doi.org/10.3390/su8050445

Jeong, Y. (2015). Architectural remodeling planning and practice. Seoul: Kimoondang. 
Jin, R., Han, S., Hyun, C., \& Cha, Y. (2016). Application of casebased reasoning for estimating preliminary duration of building projects. Journal of Construction Engineering and Management, 142(2), 04015082.

https://doi.org/10.1061/(ASCE)CO.1943-7862.0001072

Juan, Y.-K., Gao, P., \& Wang, J. (2010). A hybrid decision support system for sustainable office building renovation and energy performance improvement. Energy and Buildings, 42(3), 290297. https://doi.org/10.1016/j.enbuild.2009.09.006

Kim, G., An, S., \& Kang, K. (2004). Comparison of construction cost estimating models based on regression analysis, neural networks, and case-based reasoning. Building and Environment, 39(10), 1235-1242. https://doi.org/10.1016/j.buildenv.2004.02.013

Kim, J., Cho, K., Kim, T., \& Yoon, Y. (2018). Predicting the monetary value of office property post renovation work. Journal of Urban Planning and Development, 144(2), 04018007. https://doi.org/10.1061/(ASCE)UP.1943-5444.0000434

Kim, K. J., Yun, W. G., \& Kim, I. K. (2016). Estimating approximate construction duration of CFRD in the planning stage. KSCE Journal of Civil Engineering, 20(7), 2604-2613. https://doi.org/10.1007/s12205-016-0810-0

Kim, K., Yoon, Y., \& Kim, C. (2016). Improvements in the business process model for the aged apartment remodeling project - In case of the number of units increased. Korean Journal of Construction Engineering and Management, 17, 45-53. https://doi.org/10.6106/KJCEM.2016.17.5.045

Kim, S., Maghiar, M., Li, L., Bai, Y., \& Scott, J. (2014). Developing a knowledge-based information system (KISCCES) for construction cost estimating and scheduling. In Construction Research Congress 2014: Construction in a Global Network (pp. 887-896). https://doi.org/10.1061/9780784413517.091

Koo, C., Hong, T., Hyun, C., \& Koo, K. (2010). A CBR-based hybrid model for predicting a construction duration and cost based on project characteristics in multi-family housing projects. Canadian Journal of Civil Engineering, 37(5), 739-752. https://doi.org/10.1139/L10-007

Kragh, J., \& Rose, J. (2011). Energy renovation of single-family houses in Denmark utilising long-term financing based on equity. Applied Energy, 88(6), 2245-2253. https://doi.org/10.1016/j.apenergy.2010.12.049

Land \& Housing Institute. (2015). A study on the method of estimating the construction duration for apartment to assure quality. Seoul: Korea Land \& Housing Corporation.

Lee, B., Kim, K., \& Lee, M. (2015). A study on normal project duration for water resource project. Korean Journal of Construction Engineering and Management, 16, 35-43. https://doi.org/10.6106/KJCEM.2015.16.1.035

Li, Y., Lu, K., \& Lu, Y. (2017). Project schedule forecasting for skyscrapers. Journal of Management in Engineering, 33(3). https://doi.org/10.1061/(ASCE)ME.1943-5479.0000498

Ma, Z., Cooper, P., Daly, D., \& Ledo, L. (2012). Existing building retrofits: Methodology and state-of-the-art. Energy and Buildings, 55, 889-902.

https://doi.org/10.1016/j.enbuild.2012.08.018
Martin, J., Burrows, T. K., \& Pegg, I. (2006). Predicting construction duration of building projects. In XXIII International FIG Congress: Shaping the Change, Munich, Germany.

McCrary, S. W., Leslie, M. D., Roberts, F. L., \& Corley, M. R. (2007). Validation of project time decision-support tools and processes. Journal of Industrial Technology, 23(2), 2-14.

Nguyen, L. D., Phan, D. H., \& Tang, L. C. M. (2013). Simulating construction duration for multistory buildings with controlling activities. Journal of Construction Engineering and Management, 139(8), 951-959. https://doi.org/10.1061/(ASCE)CO.1943-7862.0000677

Nielsen, A. N., Jensen, R. L., Larsen, T. S., \& Nissen, S. B. (2016). Early stage decision support for sustainable building renovation - A review. Building and Environment, 103, 165-181. https://doi.org/10.1016/j.buildenv.2016.04.009

Ökmen, Ö., \& Öztaş, A. (2008). Construction project network evaluation with correlated schedule risk analysis model. Journal of Construction Engineering and Management, 134(1), 4963. https://doi.org/10.1061/(ASCE)0733-9364(2008)134:1(49)

Olsson, S., Malmqvist, T., \& Glaumann, M. (2015). Managing sustainability aspects in renovation processes: Interview study and outline of a process model. Sustainability, 7(6), 63366352. https://doi.org/10.3390/su7066336

Pihelo, P., Kalamees, T., \& Kuusk, K. (2017). nZEB renovation with prefabricated modular panels. Energy Procedia, 132, 1006-1011. https://doi.org/10.1016/j.egypro.2017.09.708

Reyers, J., \& Mansfield, J. (2001). The assessment of risk in conservation refurbishment projects. Structural Survey, 19(5), 238-244. https://doi.org/10.1108/02630800110412480

Statistics Korea. (2017). Retrieved from http://www.index.go.kr/ potal/main/EachDtlPageDetail.do?idx_cd=1242

Suschek-Berger, J., \& Ornetzeder, M. (2010). Cooperative refurbishment: Inclusion of occupants and other stakeholders in sustainable refurbishment processes in multi-floor residential buildings. Open House International, 35(2), 33-38.

Thuvander, L., Femenías, P., Mjörnell, K., \& Meiling, P. (2012). Unveiling the process of sustainable renovation. Sustainability, 4(6), 1188-1213. https://doi.org/10.3390/su4061188

Wang, W.-C., \& Demsetz, L. A. (2000). Model for evaluating networks under correlated uncertainty - NETCOR. Journal of Construction Engineering and Management, 126(6), 458-466. https://doi.org/10.1061/(ASCE)0733-9364(2000)126:6(458)

Yoon, J., \& Yu, I. (2017). A study on estimating normal project duration of apartment remodeling project. Korean Journal of Construction Engineering and Management, 18(2), 12-20. https://doi.org/10.6106/KJCEM.2017.18.2.012

Yoon, J., Jung, D., \& Yu, I. (2017). Factor analysis for development of construction period calculation model in apartment house remodeling. Procedia Engineering, 196, 660-665. https://doi.org/10.1016/j.proeng.2017.08.055

Yoon, J., Yu, I. \& Jung, D. (2018, September). Factors needed for the development of a constructability assessment model for building renovation and extension in Korea. In Proceedings of the 34 $4^{\text {th }}$ Annual ARCOM Conference (pp. 806-814), 3-5 September 2018. Belfast, UK: Association of Researchers in Construction Management. 